\title{
Comparison of Tree Condition and Value for City Parks and Stephen F. Austin State University in Nacogdoches, Texas, U.S.
}

\author{
David L. Kulhavy, Di Wu, Daniel R. Unger, I-Kuai Hung, and Jianghua Sun
}

\begin{abstract}
Trees in landscapes are valued for physical as well as aesthetic benefits and biodiversity. Trees on a university campus and in city parks also help to provide an environment in which students and visitors can study and relax. A critical decision facing urban foresters, arborists, and planners involves deciding when an existing tree should be removed and replaced; it is a decision often based on an evaluation of the tree's health, condition, and safety concerns. This project surveyed a total of 3,335 trees with 79 species on the campus of Stephen F. Austin State University (Nacogdoches, Texas, U.S.) and 1,572 trees with 44 species in Nacogdoches city parks. Tree health and replacement values of the two groups were statistically compared, as were the diversities of the two. Finally, the tree health conditions and distributions were spatially analyzed using a geographic information system. Although there was statistical evidence indicating that the campus trees were significantly healthier than the city park trees, neither of their biodiversity status was desirable. It is important to identify and remove trees with extensive wood decay and introduce new species when performing forest maintenance and management.

Key Words. Biodiversity; Campus; City Park; CTLA Method; Geographic Information Systems; Hazard Rating; Inventory; Risk Assessment; Species Diversity; Texas; Tree Valuation.
\end{abstract}

Trees in the landscape are valued for physical, aesthetic, and environmental benefits, as well as for their ecological biodiversity. The urban forest in city parks and at Stephen F. Austin State University (SFASU), Nacogdoches, Texas, U.S., provides an environment for education and recreation. Critical decisions facing urban foresters, arborists, and planners involve deciding whether an existing tree should be removed and replaced based on an evaluation of the tree's health, condition, and safety concerns as part of a tree maintenance program. Urban areas, with $75 \%$ of the population, contain over 3.8 billion trees covering $3.5 \%$ of the 48 contiguous United States. In the first national assessment of urban forest resources in the United States (Dwyer et al. 2000), important issues were local scale variation, complexity, connectedness of urban forest resources, and changes over time in response to external forces.

The methods to calculate tree values vary worldwide (Helliwell 1967; McGarry and Moore 1988; Flook 1996; Asociacion Española de Parques y Jardines Publicos 1999; CTLA 2000; Helliwell 2000; Watson 2002). In the United States, a method authored by the Council of Trees and Landscape Appraisers (CTLA) has been widely used since 1951 (9th edition published in 2000; CTLA 2000) in both the public and private sector due to its flexibility (Nowak et al. 2002). This method is based on a measurement of the cross-sectional area of the tree trunk at $1.4 \mathrm{~m}$ height $(\mathrm{DBH})$, multiplied by a monetary value per square inch $\left(6.45 \mathrm{~cm}^{2}\right)$. Thisis the maximum value, which is then reduced by factors for species quality, condition, and location in the landscape $(0.0$ to 1.0 for each factor). The value per square inches based on the cost of the largest commonly available trees (per square inch of trunk cross-sectional area) at regional nurseries. This cost was determined by a regional committee (CTLA 1992; CTLA 2000). The simplified formula of the CTLA method is:

[1] Appraised Value $=($ Trunk Area $\times$ Basic Price $\times$ Species $\times$ Condition $\times$ Location)

where parameters are multiplied based on area of the cross section of the trunk at 1.4 $\mathrm{m}$ in height (Grande-Ortiz et al. 2012). 
The latest version published by the International Society of Arboriculture was Guide for Plant Appraisal (CTLA 2000), incorporating four factors: size, species, condition, and location. Species ratings were regionalized for the state of Texas and are described by Dreesen (1994). The CTLA method is useful for determining the collective value of the urban forest in a community. Tree inventory data can be used to determine an average rating value for tree species (Pokorny and Albers 2003), and this value is multiplied by the total trees inventoried to calculate the urban forest value (Petijean et al. 1997). Grande-Ortiz et al. (2012) reviewed the applicability of the CTLA method and concluded that it was most suitable for street trees, parks, and forests in urban areas, with low difficulty to implement. The CTLA method is mainly for evaluation and does not consider air pollution, energy savings, and other environmental factors. Characteristics for evaluation of urban trees with the CTLA method include species, health and aesthetic value, and location. The CTLA method provides more moderate values compared to five other methods (Grande-Ortiz et al. 2008; Grande-Ortiz et al. 2012). Hollis (2012) recommends further evaluation of the microsite suitability for location in the CTLA methods.

There are three commonly used methods for evaluating biodiversity. Species Richness (S) is the total number of different organisms present and does not take into consideration the proportion and distribution of each species. Simpson index (D) is a measurement that accounts for the richness and the percent of each subspecies (horticultural variety) from a biodiversity sample within an area. This index assumes the proportion of individuals in an area and indicates their importance to diversity. The Shannon-Wiener index $(\mathrm{H})$ is similar to the Simpson index, taking into account subspecies richness and proportion of subspecies within a zone. Of the species diversity indices used, the Shannon-Wiener index $(\mathrm{H})$ is the most common (Spellerberg and Fedor 2003). Hermy and Cornelis (2000) developed a method for the general monitoring of the biodiversity in urban parks based on the Shannon-Wiener index.

Assessment and monitoring of urban forest health represents a key point for environmental policy and the management of environmental resources. The species composition, age, and size of urban forests have become complex, includ- ing impacts on the benefits derived from, and the economics for, managing urban forests (McPherson et al. 1997), the decreased size of urban forest patches, the increased isolation of urban forest patches, and the expansion of roads. These factors have negative effects on native biodiversity. Through proper management, these trends can be reversed, or at least slowed. Progress toward urban forest recovery can be measured through the use of ecological indicators that correspond to the specific conditions and trends of concern (Noss 1999).

Since the completion of the Global Positioning System (GPS) in 1995, the integration of GPS and Geographic Information Systems (GIS) technology has expanded rapidly for ecological and conservation applications. GIS is an information technology with the capacity to retrieve, store, analyze, and display both spatial and non-spatial data (Parker 1988). Using GPS and GIS, trees in an urban area can be inventoried with high efficiency and precision.

To determine the current replacement value and forest health condition in the 26 Nacogdoches city parks and the SFASU campus, trees were appraised using the Evaluation of Texas Shade Trees formula (Dreesen 1994) based on the standards of the Council of Trees and Landscape Appraisers (CTLA 1992; CTLA 2000). Each tree was measured for species, size, condition, growth, structure, insects and disease, life expectancy, and location. Species richness, species evenness, Shannon-Weiner index, and Simpson index were calculated to analyze the biodiversity of the SFASU campus and city parks.

\section{METHODS}

\section{Field Measurement}

In 26 Nacogdoches city parks and cemeteries and the SFASU campus, each tree $>10 \mathrm{~cm}$ diameter at $1.4 \mathrm{~m}$ in the parks and on campus was located using a Trimble Pathfinder ProXRS GPS unit to an accuracy of $1 \mathrm{~m}$. The geographic coordinates of each tree along with its attributes were entered into an ArcGIS 10.1 (ESRI, Redlands, California, U.S.) geodatabase in the GIS Laboratory, Arthur Temple College of Forestry and Agriculture, SFASU. Initial tree locations for SFASU were located by Perkins (1996) and updated in 2005 and 2010. City park trees were rated in 2005 and data updated in 2008. For the city parks, trees with a diameter $>10 \mathrm{~cm}$ at $1.4 \mathrm{~m}$ and lo- 
cated within $30.5 \mathrm{~m}$ of a main area of use (pavilions, playgrounds, restrooms) were measured. For SFA$\mathrm{SU}$, trees were measured in the core part of campus.

\section{Tree Value Assessment}

Mapped trees were evaluated to determine the U.S. dollar value and to calculate biodiversity and health condition using the Texas Shade Tree Valuation Formula (Dreesen 1994) based on the CTLA method (CTLA 2000). The four variables measured were size, species, condition, and location, as used in the following formula:

[2] Value $=\mathrm{N} \times$ Size $\times$ Species Class $\times$ Condition $\times$ Location

where $\mathrm{N}=$ value per square inch of cross-sectional areal; USD $\$ 75$ per $6.5 \mathrm{~cm}^{2}$, a value of $\$ 75$ for $\mathrm{N}$ was used for this study; Size = cross-sectional area in square inches based on diameter in inches at $1.4 \mathrm{~m},(\mathrm{DBH})^{2}$ times 0.7854; Species Class $=1.0,0.80,0.60$, or 0.10 depending on the species; and Condition $=$ percentage of health value.

Condition is based on a scale of 1-5 (1 being the lowest) for Trunk, Structure, Crown Development, and Life Expectancy; and a scale of 1-3 for Insects and Disease and Growth. Variable ratings for condition are:

- Trunk Condition: sound and solid, 5; missing section of bark, 3; extensive decay, 1

- Growth: vigorous, 3; moderate, 2; poor, 1

- Crown Structure: sound, 5; one major or several limbs dead, broken, or missing, 4; two or more major limbs dead, broken, or missing, 1

- Insects and Disease: no pests, 3; one pest 2; two or more pests, 1

- Crown Development: full and dense crowns with balanced growth, 5 ; full but unbalanced 3; unbalanced and lacking a full crown, 1

- Life Expectancy: more than 20 years, 5; 15 to 20 years, 3; less than 5 years, 1 . Life expectancy was estimated based on species, location, condition variables of the trunk, growth, structure of the crown, presence of absence of insects and diseases, and growing area available. Data for age for removal for campus trees were based on the rate of removal for the past 20 years, and for the last 10 years for Nacogdoches parks trees. Smiley and Baker (1988) indicate life expectancy is not easy to determine; however, the CTLA method provides ranges for estimated time of removal. Hollis (2012) indicates the comparative age of a tree and its current life expectancy should be consistent with International Valuation Standards (IVSC 2005). The remaining life expectancy of a tree is part of the Condition factor in Guide for Plant Appraisal (CTLA 2000). For condition, a total score of 26 is $100 \%$ of condition (maximum of each variable); the minimum value is 6 out of 26 (23\%). These trees did not have visible crown or trunk defects or pest problems; and the growth and longevity were considered optimum for the site.

- Location: This value refers to the placement of the plant within the landscape. Since all the trees involved in this evaluation are park or campus trees, this value was $70 \%$ of value (Dreesen 1994).

In the GIS geodatabase, each tree was calculated in the attribute table for its value as a function of the five variables (value, size, species, condition, and location). Another attribute field was added assuming the rating of the six Condition variables was a 26 out of 26 rating, therefore $100 \%$ as the Condition value. The difference between the field-measured value and the tree in optimum health condition value was compared as a measure of loss for the parks and university trees.

The central research question was to compare tree health, as measured by condition and species, between the Nacogdoches city park trees and the SFASU campus trees. The overall tree health condition values and the six variables, which determine the condition values (trunk, growth, structure, insect and disease, crown development, and life expectancy), were compared between the two groups. A t-test (alpha 0.05) was conducted on each variable to determine if there was a significant difference between the two. The test applied to all trees in two groups. In addition, the same test was performed on those individual species where 30 
or more trees were observed. Data were analyzed using Statistical Analysis Software (SAS) version 9.1 (SAS Institute, Cary, North Carolina, U.S.).

\section{Biodiversity}

The Shannon-Wiener index and Simpson index were calculated and compared to analyze the biodiversity for each park and for the SFASU campus. The Shannon-Wiener index was calculated based on the following formula:

$$
H^{\prime}=\sum\left(p_{i}\right)\left(\ln p_{i}\right)
$$

where $\mathrm{H}^{\prime}=$ index of diversity, and $\mathrm{p}_{\mathrm{i}}=$ proportion of total sample belonging to $\mathrm{i}^{\text {th }}$ species. The species biodiversity including evenness and richness were analyzed based on the result of Shannon-Wiener index.

Simpson's index D measures the probability that two individuals randomly selected from a sample will belong to the same species, and was calculated based on the following formula:

$$
D=\frac{\sum n(n-1)}{N(N-1)}
$$

where $\mathrm{n}=$ the total number of organisms of a particular species and $\mathrm{N}=$ the total number of organisms of all species. With this index, 0 represents infinite diversity and 1 indicates no diversity. That is, the bigger the value of $\mathrm{D}$, the lower the diversity. This is neither intuitive nor logical. In order to get over this problem, $\mathrm{D}$ is often subtracted from 1 to derive the value of Simpson's Index of Diversity: $1-\mathrm{D}$. This index also ranges between 0 and almost 1 . In this case, the greater the value is, the greater the diversity. Another derivative is Simpson's Reciprocal Index: 1 / D, which starts with 1 as the lowest possible value representing a community having only one species. For this study, all the three indices-Simpson's index D, Simpson's index $1-\mathrm{D}$, and Simpson's index 1/D-were calculated. Higher values represent greater diversity.

\section{Spatial Analysis}

Within the Spatial Statistics toolbox in ArcGIS 10.1, the Mean Center and Standard Distance tool were used to identify the geographic center for trees and the core area in each park and the campus. On the output, the center of the trees in a study area was located and the standard distance circle was drawn to identify the core of the study area. This core area assisted in separating trees into two geographic groups: center trees and edge trees. A t-test (alpha 0.05 ) on tree health condition was conducted to see if there was any significant difference between the two groups of trees in each study area.

\section{RESULTS}

For SFASU campus, a total of 3,335 trees were measured and 79 species identified. The most abundant species was Pinus taeda (loblolly pine) with 1,508 trees. Other abundant species included Quercus nigra (water oak, 180 trees), Lagerstroemia indica (crapemyrtle, 158 trees), Liquidambar styraciflua (sweetgum, 148 trees), and Pinus echinata (shortleaf pine, 122 trees). Thirteen of the 79 species were identified as having more than 50 individuals, and 59 of the 79 species were less than 30 individuals.

For city park trees, a total of 1,572 trees were measured in 26 city parks and cemeteries with 44 species identified. Carya illinoinensis (pecan) was the most abundant species with 292 trees. Other abundant species included Pinus echinata (shortleaf pine, 159 trees), Quercus virginiana (live oak, 153 trees), and Pinus taeda (loblolly pine, 131 trees). Thirty-two of the total 44 species had less than 30 individual trees.

For the tree species with more than 30 individuals, the health condition ratings for the SFASU campus trees were significantly greater than the city park trees (Table 1), indicating they were healthier. Among the twelve species, only three species (Pinus echinata, Quercus stellata, and Ulmus americana) did not differ between SFASU and park trees $(P>$ $0.05)$. The campus tree species with the highest overall condition rating of $89 \%$ was Q. virginiana and the park tree species was $77 \%$ for Q. stellata. The campus tree species with the lowest overall condition rating of $68 \%$ was P. echinata and the park tree species was $63 \%$ for Q. nigra (Table 1).

The condition variables (trunk, growth, structure, disease and insect, crown development, and life expectancy) were compared for SFASU campus and city park trees (Table 2). Celtis laevigata, Pinus taeda, Ulmus alata, and Liquidambar styraciflua of campus trees compared to park trees were significantly higher in all condition variables except crown development. Juniperus virginiana campus trees were significantly higher in all variables except growth and crown development. For Pinus echinata, 
campus trees were significantly higher in only mean growth, whereas park trees were significantly higher in crown structure with fuller and denser crowns. Quercus falcata campus trees were rated significantly higher in insects and diseases (fewer insects and diseases) and life expectancy, while park trees of the same species were significantly higher in trunk condition and crown structure. Campus trees of Quercus nigra were significantly higher in all condition variables when compared to park trees. Campus trees of Quercus stellata were significantly greater in growth than park trees. For Quercus virginiana, campus trees were significantly higher in insects and disease than park trees, whereas park trees were significantly higher in growth. Ulmus americana campus trees were significantly higher in insects and diseases and life expectancy than those of park trees (Table 2).

The highest-rated trunk condition of 4.3 was for P. taeda campus trees and 4.1 for Q. falcata for park trees. The highest-rated growth was 3.0 for Q. stellata campus trees and 2.6 for both Q. stellata and
Q. virginiana park trees. The highest-rated structure was 4.7 for Q. virginiana campus trees and 3.8 for Q. stellata park trees. The highest insects and disease rating was 2.9 for $Q$. virginiana campus trees and 2.7 for Q. stellata park trees. The highest-rated crown shape was 4.6 for $Q$. virginiana campus trees and 4.0 for $Q$. virginiana park trees. The highest life expectancy was 4.7 for Q. virginiana campus trees and 4.2 for $Q$. virginiana park trees.

The lowest-rated trunk condition was 3.8 for campus trees and 3.1 for park trees, both for C. laevigata. The lowest-rated growth was 2.4 for campus trees and 2.2 for park trees, both for J. virginiana. The lowest structure was 2.8 for $P$. echinata campus trees and 2.0 for C. laevigata park trees. The lowest insects and disease rating was 2.2 for J. virginiana campus trees and 1.8 for C. laevigata park trees. The lowest-rated crown shape was 2.8 for $P$. echinata campus trees and 2.1 for Liquidambar styraciflua park trees. The lowest life expectancy was 3.7 for campus trees and 3.1 for park trees, both at U. americana (Table 2).

Table 1. Average tree health condition comparison for the major species ( 30 individuals or more) between the SFASU campus and the city parks.

\begin{tabular}{|c|c|c|c|c|}
\hline Species & Location & Average condition (std.) & $P$-value of $\mathrm{t}$-test & Better health condition \\
\hline Carya illinoinensis & $\begin{array}{l}\text { Campus }(\mathrm{n}=33) \\
\text { Park }(\mathrm{n}=292)\end{array}$ & $\begin{array}{l}77 \%(0.1) \\
67 \%(0.1)\end{array}$ & $<0.001$ & Campus \\
\hline Celtis laevigata & $\begin{array}{l}\text { Campus }(\mathrm{n}=96) \\
\text { Park }(\mathrm{n}=69)\end{array}$ & $\begin{array}{l}74 \%(0.2) \\
68 \%(0.2)\end{array}$ & 0.02 & Campus \\
\hline Juniperus virginiana & $\begin{array}{l}\text { Campus }(\mathrm{n}=85) \\
\text { Park }(\mathrm{n}=59)\end{array}$ & $\begin{array}{l}76 \%(0.2) \\
65 \%(0.2)\end{array}$ & $<0.0001$ & Campus \\
\hline Liquidambar styraciflua & $\begin{array}{l}\text { Campus }(\mathrm{n}=148) \\
\text { Park }(\mathrm{n}=110)\end{array}$ & $\begin{array}{l}80 \%(0.2) \\
64 \%(0.2)\end{array}$ & $<0.0001$ & Campus \\
\hline Pinus echinata & $\begin{array}{l}\text { Campus }(\mathrm{n}=122) \\
\text { Park }(\mathrm{n}=159)\end{array}$ & $\begin{array}{l}68 \%(0.2) \\
71 \%(0.2)\end{array}$ & 0.14 & N/A \\
\hline Pinus taeda & $\begin{array}{l}\text { Campus }(\mathrm{n}=1508) \\
\text { Park }(\mathrm{n}=131)\end{array}$ & $\begin{array}{l}81 \%(0.2) \\
71 \%(0.1)\end{array}$ & $<0.0001$ & Campus \\
\hline Quercus falcata & $\begin{array}{l}\text { Campus }(\mathrm{n}=53) \\
\text { Park }(\mathrm{n}=99)\end{array}$ & $\begin{array}{l}76 \%(0.1) \\
70 \%(0.1)\end{array}$ & 0.01 & Campus \\
\hline Quercus nigra & $\begin{array}{l}\text { Campus }(\mathrm{n}=180) \\
\text { Park }(\mathrm{n}=109)\end{array}$ & $\begin{array}{l}84 \%(0.1) \\
63 \%(0.1)\end{array}$ & $<0.0001$ & Campus \\
\hline Quercus stellata & $\begin{array}{l}\text { Campus }(\mathrm{n}=30) \\
\text { Park }(\mathrm{n}=71)\end{array}$ & $\begin{array}{l}79 \%(0.1) \\
77 \%(0.1)\end{array}$ & 0.62 & N/A \\
\hline Quercus virginiana & $\begin{array}{l}\text { Campus }(\mathrm{n}=97) \\
\text { Park }(\mathrm{n}=153)\end{array}$ & $\begin{array}{l}89 \%(0.1) \\
72 \%(0.1)\end{array}$ & $<0.0001$ & Campus \\
\hline Ulmus alata & $\begin{array}{l}\text { Campus }(\mathrm{n}=82) \\
\text { Park }(\mathrm{n}=55)\end{array}$ & $\begin{array}{l}81 \%(0.2) \\
64 \%(0.2)\end{array}$ & $<0.0001$ & Campus \\
\hline Ulmus americana & $\begin{array}{l}\text { Campus }(\mathrm{n}=34) \\
\text { Park }(\mathrm{n}=31)\end{array}$ & $\begin{array}{l}75 \%(0.2) \\
65 \%(0.2)\end{array}$ & 0.05 & $\mathrm{~N} / \mathrm{A}$ \\
\hline
\end{tabular}


Table 2. Comparison on trunk, growth, crown structure, disease and insect, crown development, and life expectancy for the major species ( 30 individuals or more) on the SFASU campus and in the city parks.

\begin{tabular}{|c|c|c|c|c|c|c|c|}
\hline Species & Location & $\begin{array}{l}\text { Trunk } \\
\text { mean (SD) }\end{array}$ & $\begin{array}{l}\text { Growth } \\
\text { mean }(S D)\end{array}$ & $\begin{array}{l}\text { Crown structure } \\
\text { mean }(\mathrm{SD})\end{array}$ & $\begin{array}{l}\text { Disease insect } \\
\text { mean }(\mathrm{SD})\end{array}$ & $\begin{array}{l}\text { Crown development } \\
\text { mean (SD) }\end{array}$ & $\begin{array}{l}\text { Life expectancy } \\
\text { mean (SD) }\end{array}$ \\
\hline \multirow[t]{3}{*}{ Carya illinoinensis } & Campus $(\mathrm{n}=32)$ & $3.9(0.9)$ & $2.7(0.5)$ & $3.5(1.2)$ & $2.7(0.5)$ & $3.4(1.1)$ & $3.9(1.0)$ \\
\hline & Park $(n=292)$ & $3.5(1.0)$ & $2.5(0.7)$ & $3.1(1.0)$ & $2.0(0.6)$ & $3.3(0.8)$ & $3.1(0.9)$ \\
\hline & $P$-value of $\mathrm{t}$-test & 0.005 & 0.200 & 0.044 & $<0.0001$ & 0.654 & $<0.0001$ \\
\hline \multirow[t]{3}{*}{ Celtis laevigata } & Campus $(\mathrm{n}=96)$ & $3.8(1.3)$ & $2.5(0.7)$ & $3.8(1.3)$ & $2.4(0.7)$ & $3.0(1.0)$ & $3.9(1.2)$ \\
\hline & $\operatorname{Park}(\mathrm{n}=69)$ & $3.1(1.3)$ & $2.2(0.7)$ & $2.0(1.2)$ & $1.8(0.6)$ & $3.0(1.2)$ & $3.1(1.2)$ \\
\hline & $P$-value of $\mathrm{t}$-test & 0.0008 & 0.0076 & 0.0003 & $<0.0001$ & 0.9894 & 0.0002 \\
\hline \multirow[t]{3}{*}{ Juniperus virginiana } & Campus $(\mathrm{n}=85)$ & $4.1(1.2)$ & $2.4(0.6)$ & $3.7(1.2)$ & $2.2(0.8)$ & $3.4(1.4)$ & $3.9(1.2)$ \\
\hline & $\operatorname{Park}(\mathrm{n}=59)$ & $3.2(1.1)$ & $2.2(0.9)$ & $3.1(0.9)$ & $1.9(0.7)$ & $3.2(1.0)$ & $3.3(0.9)$ \\
\hline & $P$-value of $\mathrm{t}$-test & $<0.0001$ & 0.0937 & 0.0012 & 0.0329 & 0.209 & 0.0006 \\
\hline \multirow[t]{3}{*}{ Liquidambar styraciflua } & Campus $(\mathrm{n}=148)$ & $4.1(1.2)$ & $2.9(0.5)$ & $3.6(1.3)$ & $2.8(0.6)$ & $3.4(1.3)$ & $4.2(1.2)$ \\
\hline & $\operatorname{Park}(\mathrm{n}=110)$ & $3.6(1.1)$ & $2.4(0.6)$ & $3.2(1.1)$ & $2.3(0.7)$ & $2.1(1.0)$ & $3.5(1.1)$ \\
\hline & $P$-value of $\mathrm{t}$-test & 0.0012 & $<0.0001$ & 0.0123 & $<0.0001$ & 0.1321 & $<0.0001$ \\
\hline \multirow[t]{3}{*}{ Pinus echinata } & Campus $(\mathrm{n}=122)$ & $3.6(1.2)$ & $2.7(0.7)$ & $2.8(1.1)$ & $2.2(0.7)$ & $2.8(1.1)$ & $3.5(1.1)$ \\
\hline & Park $(\mathrm{n}=159)$ & $3.6(1.0)$ & $2.5(0.7)$ & $3.5(0.9)$ & $2.2(0.8)$ & $3.3(0.9)$ & $3.7(0.9)$ \\
\hline & $P$-value of $\mathrm{t}$-test & 0.9416 & 0.0112 & $<0.0001$ & 0.6412 & $<0.0001$ & 0.2638 \\
\hline \multirow{3}{*}{ Pinus taeda } & Campus $(\mathrm{n}=1508)$ & $4.3(1.0)$ & $2.8(0.5)$ & $3.8(1.2)$ & $2.6(0.6)$ & $3.3(1.1)$ & $4.3(1.0)$ \\
\hline & $\operatorname{Park}(\mathrm{n}=131)$ & $3.9(0.8)$ & $2.3(0.7)$ & $3.3(0.9)$ & $2.3(0.7)$ & $3.5(1.0)$ & $3.7(0.8)$ \\
\hline & $P$-value of $\mathrm{t}$-test & $<0.001$ & $<0.0001$ & $<0.0001$ & $<0.0001$ & 0.0025 & $<0.0001$ \\
\hline \multirow[t]{3}{*}{ Quercus falcata } & Campus $(\mathrm{n}=53)$ & $3.8(1.1)$ & $2.6(0.6)$ & $3.4(1.3)$ & $2.8(0.5)$ & $3.1(1.1)$ & $4.1(1.0)$ \\
\hline & Park $(\mathrm{n}=99)$ & $4.1(0.9)$ & $2.6(0.6)$ & $3.3(1.1)$ & $2.3(0.7)$ & $3.5(1.0)$ & $3.7(0.9)$ \\
\hline & $P$-value of $\mathrm{t}$-test & 0.0346 & 0.4288 & 0.6657 & $<0.0001$ & 0.0124 & 0.0196 \\
\hline \multirow[t]{3}{*}{ Quercus nigra } & Campus $(\mathrm{n}=180)$ & $4.2(1.0)$ & $2.9(0.4)$ & $3.8(1.2)$ & $2.7(0.5)$ & $3.8(1.1)$ & $4.4(0.9)$ \\
\hline & Park $(\mathrm{n}=109)$ & $3.7(1.0)$ & $2.4(0.7)$ & $3.0(1.2)$ & $2.00(0.7)$ & $3.3(1.2)$ & $3.4(1.1)$ \\
\hline & $P$-value of $\mathrm{t}$-test & $<0.0001$ & $<0.0001$ & $<0.0001$ & $<0.0001$ & 0.0006 & $<0.0001$ \\
\hline \multirow[t]{3}{*}{ Quercus stellata } & Campus $(\mathrm{n}=30)$ & $3.9(1.0)$ & $3.0(0.2)$ & $3.3(1.2)$ & $2.8(0.4)$ & $3.8(1.2)$ & $3.8(0.7)$ \\
\hline & Park $(\mathrm{n}=71)$ & $3.8(1.0)$ & $2.6(0.6)$ & $3.8(1.0)$ & $2.7(0.6)$ & $3.7(0.9)$ & $4.0(0.8)$ \\
\hline & $P$-value of $\mathrm{t}$-test & 0.476 & $<0.0001$ & 0.0522 & 0.499 & 0.7565 & 0.2711 \\
\hline \multirow[t]{3}{*}{ Quercus virginiana } & Campus $(\mathrm{n}=97)$ & $3.8(1.1)$ & $2.5(0.6)$ & $4.7(0.6)$ & $2.9(0.3)$ & $4.6(0.7)$ & $4.7(0.6)$ \\
\hline & Park $(\mathrm{n}=153)$ & $3.7(0.8)$ & $2.6(0.6)$ & $3.7(0.8)$ & $2.1(0.5)$ & $4.0(0.8)$ & $4.2(0.6)$ \\
\hline & $P$-value of $\mathrm{t}$-test & 0.222 & 0.048 & $<0.0001$ & $<0.0001$ & $<0.0001$ & $<0.0001$ \\
\hline \multirow[t]{3}{*}{ Ulmus alata } & Campus $(\mathrm{n}=82)$ & $4.1(1.1)$ & $2.7(0.6)$ & $3.9(1.2)$ & $2.8(0.5)$ & $3.4(1.1)$ & $4.3(0.9)$ \\
\hline & $\operatorname{Park}(\mathrm{n}=55)$ & $3.5(1.2)$ & $2.4(0.7)$ & $3.2(1.1)$ & $2.2(0.7)$ & $3.2(1.1)$ & $3.4(1.0)$ \\
\hline & $P$-value of $\mathrm{t}$-test & 0.005 & 0.0012 & 0.002 & $<0.0001$ & 0.339 & $<0.0001$ \\
\hline \multirow[t]{3}{*}{ Ulmus americana } & Campus $(\mathrm{n}=34)$ & $3.9(1.2)$ & $2.6(0.7)$ & $3.5(1.5)$ & $2.6(0.7)$ & $3.2(1.2)$ & $3.7(1.3)$ \\
\hline & $\operatorname{Park}(\mathrm{n}=31)$ & $3.4(1.1)$ & $2.3(0.6)$ & $3.0(1.1)$ & $1.9(0.8)$ & $2.9(1.1)$ & $3.1(1.1)$ \\
\hline & $P$-value of $\mathrm{t}$-test & 0.1043 & 0.1073 & 0.1047 & 0.0004 & 0.4583 & 0.0346 \\
\hline
\end{tabular}

Pinus echinata, Quercus stellata, and Ulmus americana were not significantly different in tree health condition between campus trees and park trees. The other seven species with significant difference in tree health also resulted in a great difference in trunk values, except $Q$. virginiana. Undesired trunk condition and wood decay were among the most significant tree problems.

When all trees were analyzed instead of only major species $(\mathrm{n} \geq 30)$, SFASU campus trees had a significantly higher health condition $(78 \%)$ than that of city park trees (72\%). As to the six condi- tion variables, SFASU campus trees had significantly higher ratings than city park trees for all of the variables except crown development (Table 3). For campus trees, only one species (P. echinata) was under $70 \%$ of condition, while six park species were under $70 \%$ of condition. Of the most abundant species on campus, $P$. taeda $(\mathrm{n}=1,508)$, the condition rating was $81 \%$, followed by $Q$. nigra $(\mathrm{n}=180)$ with the condition rating of $84 \%$. For city park trees, the most abundant species, C. illinoinensis $(\mathrm{n}=292)$, the condition was rated was $67 \%$, and with the second abundant species, P. echinata $(\mathrm{n}=159)$, rated as $71 \%$ 
Table 3. Comparison of tree health condition between the SFASU campus and the city parks.

\begin{tabular}{|c|c|c|c|c|}
\hline Condition class & $\begin{array}{l}\text { SFASU campus } \\
\text { average rating (SD) }\end{array}$ & $\begin{array}{l}\text { City park } \\
\text { average rating (SD) }\end{array}$ & $\begin{array}{l}P \text {-value of } \\
\text { t-test }\end{array}$ & Better condition \\
\hline Trunk (1-5) & $4.0(1.3)$ & $3.6(1.0)$ & $<0.0001$ & Campus \\
\hline Growth (1-3) & $2.7(0.7)$ & $2.5(0.7)$ & $<0.0001$ & Campus \\
\hline Crown structure $(1-5)$ & $3.7(1.4)$ & $3.3(1.0)$ & $<0.0001$ & Campus \\
\hline Insects/Diseases (1-3) & $2.6(0.7)$ & $2.2(0.7)$ & $<0.0001$ & Campus \\
\hline Crown development (1-5) & $3.4(1.3)$ & $3.4(1.0)$ & 0.4324 & $\mathrm{~N} / \mathrm{A}$ \\
\hline Life expectancy $(1-5)$ & $4.1(1.2)$ & $3.6(1.0)$ & $<0.0001$ & Campus \\
\hline Total $(0 \%-100 \%)$ & $78 \%(0.2)$ & $72 \%(0.2)$ & $<0.0001$ & Campus \\
\hline
\end{tabular}

Based on the Texas Agriculture Extension Service's Evaluation of Texas Shade Trees, a dollar value was calculated for each tree. When using $\$ 75$ as the International Society of Arboriculture (ISA) value per square inch of cross-sectional area, the total value of all trees on SFASU campus $(\mathrm{n}=3,345)$ was over $\$ 27$ million $(\$ 27,251,104)$ with individual values ranging from $\$ 0$ (dead trees) to $\$ 89,780$, which was a Quercus virginiana. The average value of the campus trees was $\$ 8,179$. If all the trees were in perfect condition (assume condition value as 1.0 ), the total dollar value would be more than $\$ 35$ million $(\$ 35,018,000)$ for all campus trees, which is more than $\$ 8$ million difference from the current condition.

For city park trees, the total value of the 1,572 trees was $\$ 20,735,279$ based on unit value of $\$ 75$. Values ranged from $\$ 0$ (dead tree) to $\$ 79,317$, which was a Quercus nigra located in Oak Grove Cemetery. The average value of the city park trees was $\$ 13,190$. If all were in optimum condition (referred to as perfect by Dreesen 1994)-26 out of 26 -the total dollar value would increase to $\$ 28,848,824$. The use of the CTLA method incorporates the evaluator's expertise in evaluation of the physical tree characteristics and how these characteristics affect value. The CTLA method integrates valuation with readily available tree parameters, location, and species information (Cullen 2007). Trees evaluated in excellent condition could have minor leaf or needle defoliation or discoloration that did not diminish the overall quality. While there is no perfect tree, evaluators need to take into consideration the impact of biotic and abiotic influences on the tree in its location, species, and condition. When the two groups were compared, SFASU campus trees had lower average value than those of the city parks, although campus trees had a greater total value due to its larger population.
Table 4. Comparison of biodiversity between the SFASU campus trees and the city park trees.

\begin{tabular}{lll}
\hline & SFASU campus & City parks \\
\hline Total (N) & 3,335 & 1,572 \\
Richness (S) & 72 & 45 \\
Shannon-Wiener Index of Diversity (H) & 2.6 & 2.9 \\
Species Pielou's Evenness (H/lns) & 0.6 & 0.7 \\
Simpson's Index D & 0.2 & 0.1 \\
Simpson's Index of Diversity 1 - D & 0.8 & 0.9 \\
Simpson's Reciprocal Index 1 / D & 4.6 & 12.1 \\
\hline
\end{tabular}

The Shannon-Wiener index $(\mathrm{H})$ for SFASU campus trees and city park trees resulted in close values with city park tree (2.9) slightly greater than SFASU campus trees (2.6) (Table 4). For the 3,335 measured SFASU campus trees, there were 79 species with an Evenness value of 0.6 calculated. For the city park trees $(n=1,572)$, species Richness is 44 and Evenness 0.7. Although the species Richness at SFASU campus is higher than in city parks, all the Simpson's index values indicated greater diversity in city parks, which is in agreement with the Shannon-Wiener's index result. However, Simpson's index gives more weight to the more abundant species in a sample.

Although rich and diverse in species, trees in the study area are unevenly distributed. The population on SFASU campus tree is dominated by Pinus taeda. Some city parks are dominated by a single species, such as Carya illinoinensis in Pecan Park. That is not desirable for tree management and disease control, and will negatively affect tree health.

Spatial analysis applied to the SFASU main campus and the three largest city parks, Pecan Park, Maroney Park, and Pioneer Park, separated trees within each area into two geographic groups, Center and Edge. The results showed that trees growing on the edge had a better health condition than trees located at the center for both Pioneer Park $(P=0.038)$ and the SFASU campus $(P<0.0001)$. No significant difference was found for Pecan Park and Maroney Park (Table 5). 
Table 5. Comparison of center and edge tree condition between the SFASU campus and three city parks.

\begin{tabular}{llll}
\hline Location & Number of trees & $\begin{array}{l}\text { Average tree } \\
\text { condition }(\mathrm{SD})\end{array}$ & P-value of t-test \\
\hline SFASU Campus & $\begin{array}{l}\text { Center }(\mathrm{n}=1705) \\
\text { Edge }(\mathrm{n}=1630)\end{array}$ & $0.77(0.21)$ & $<0.0001$ \\
& Center $(\mathrm{n}=191)$ & $0.80(0.18)$ & 0.038 \\
Pioneer Park & Edge $(\mathrm{n}=122)$ & $0.62(0.15)$ & 0.18 \\
& Center $(\mathrm{n}=162)$ & $0.65(0.14)$ & Edge tree \\
Pecan Park & Edge $(\mathrm{n}=117)$ & $0.62(0.18)$ & 0.46 \\
& Center $(\mathrm{n}=160)$ & $0.75(0.12)$ & N/A \\
\hline
\end{tabular}

\section{DISCUSSION}

Similar tree studies on the SFASU campus have been conducted previously. The initial study in 1971 was based on a portion of the campus and recorded 38 species (Nixon and Mims 1971), 30 species in 1992 (Creech et al. 1994), 37 species in 1994 study (Perkins 1996), and 30 species in 2008. Many of the trees lost or damaged in 1994 were located near new sidewalk construction and utility lines. Also, many of the species reported in 1994 were removed and not replaced. They included the native species Prunus caroliniana (cherry laurel) and the exotic species Ligustrum sp. (privet), Eucalyptus camaldulensis var. camaldulensis (river red gum), E. ovata (swamp gum), E. robusta (swamp mahogany), E. camldulensis var. obtusa (river red gum), and Prunus mexicana (Mexican plum).

For urban forest management, several aspects should be considered, including the desire and needs of the community, the urban forest structure, inventory and monitoring, and dialogue among owners, managers, and users (Dwyer et al. 2000). Trees dead or in poor condition should be considered for removal and replanting. Developing a management plan for these issues requires adopting an expanded set of goals incorporating environmental processes and conditions at a larger scale than the individual tree. One of the most important tree problems of both SFASU campus and city park trees was trunk decay, progressive deterioration of woody tissue in both living and dead trees (Nicholas and Crawford 2003). Wood decay in a living tree in the middle of a park could result in limb or trunk breakage during adverse weather. Trees with a low rating of trunk condition have a high rating of insect and disease.

As trunk decay increases, as noted by missing bark and evident decay at the base or on the trunk, care must be taken in further analysis of decay. Indicators of decay of branches, the trunk, and the root collar need to be carefully assessed for signs and symptoms of decay and pathogens. Indicators include fungal conks, cavities or openings, and carpenter ant (Camponotus spp.) nests (Luley 2012). Kane et al. (2001) and Kane and Ryan (2004) review strength loss and compare methods between estimation of loss as a function of stem hollow percentage cautioning that deciding on hazardous and non-hazardous trees is complicated, and "Hazard tree assessment is an art as much as it is a science ... It is better to approach hazard tree assessment as risk management" (Kane et al. 2001). Methods of searching for decay include use of the IML-RESISTOGRAPH ${ }^{\circ}$ to detect hollow areas of the trunk or branches and calculate strength loss (Johnstone et al. 2007; Johnstone et al. 2010) and the PiCUS Sonic Tomograph for quantification of decay (Gilbert and Smiley 2004). Pokorny (2003) presents urban tree risk assessment incorporating a tree risk management plan (Hauer and Johnson 2003; Pokomy and Albers 2003) including risk inspections; and detection and assessment of hazardous defects in trees (Albers et al. 2003) including decay detection devices benefits and limitations. Therefore, it is important to identify decay in the urban forest and the care needs to be taken in the evaluation of the trees selected for removal. All defective trees cannot be detected, corrected, or eliminated. Root problems and internal defects are not easily discernible and inspections need to be made to determine change in the CTLA rating prompting additional management. Albers et al. (2003) stress seven categories of defects for trees: decayed wood; cracks; root problems; weak branch unions; cankers; poor tree architecture; and dead trees, tops, and branches. 
Risk assessment guidelines for these categories are presented, including moderate and high risk of failure along with commonly found defects by species.

Trees with a lower CTLA rating can be revisited on an inspection schedule. Pokorny and Albers (2003) recommend an annual visit for very high hazard areas and one to two years for high hazard areas. Moderate and low hazard areas range from three to five years for individual tree inspections. Tree inspections are needed as tree structure and vigor change over time and risk inspections provide a continuous source of tree resource data as a foundation for a comprehensive management system (Pokorny and Albers 2003).

In overall health condition, SFASU campus trees were significantly better compared to city park trees for the 12 major species $(n \geq 30)$ except for Q. stellata and U. americana (Table 1).

As a guide to achieve biodiversity for shade trees, the 10-20-30 rule is often used. The rule states that no more than $10 \%$ of the urban forest should be of the same species; no more than $20 \%$ of the forest should be of the same genus, and no more than $30 \%$ of the community's tree inventory should be a single family. These guidelines result in a more biologically diverse planting (Santamour 2004). In both the SFASU campus and the city parks, the species and genus composition exceeded these guidelines (i.e., $P$. taeda on the SFASU campus and C. illinoinensis in the city parks). Tree plantings need to be organized with consideration to growing space, species composition, and long-term use of either the campus or city parks. Planting organizers need to take into consideration increasing species diversity and examine the current urban forest for additional management, including Celtis laevigata (sugarberry) and Q. nigra. An examination of tree condition (Table 1; Table 2) indicates species that need additional maintenance.

Using the 10-20-30 rule as a guide and associating the results with both Shannon-Wiener and Simpson's indices, the biodiversity of both SFASU campus trees and city parks trees were not adequate. The 10-20-30 rule was developed with the goal or preventing or avoiding catastrophic losses. This rule may not consider cultivars or species within the same genus. Recommendations include diversification at the generic, familial, and even ordinal level (Raupp et al. 2006). Santamour (2004) and
Raupp et al. (2006) point out that new introduced pests can virtually eliminate urban forest trees, as with Dutch elm disease on American elm (Ulmus americana) and chestnut blight (Cryphonectria parasitica) on American chestnut (Castanea dentate). Other examples include the introduced emerald ash borer (Agrilus planipennis) on ash (Fraxinus spp.) (Vannatta et al. 2012) and Asian longhorned beetle (Anoplophora glabripennis) on maple (Acer spp.). Recommendations include diversifying the species of trees planted in urban areas (Raupp et al. 2006). Increasing biodiversity increases the urban forest's capacity to recover from drought, wind damage, and management actions (Fischer et al. 2006). Promotion of biodiversity increases both the social and ecological benefits of the urban forest and planning needs to incorporate both native species and cultivars that are not invasive (Alvey 2006). Care must be taken with nonnative and invasive species as urban forests often serve as an introduction point for these species [e.g., Chinese tallow (Triadica sebifera)] (Webster et al. 2006). Chinese tallow may have a competitive advantage with growth and reproduction over other species (Rogers and Siemann 2005; Schaefer 2009). With the high percentage of $P$. taeda on the university campus, measures can be taken to increase species diversity in new planting while keeping the overstory pine. The university and the city could introduce new species or increase the plantings of some existing species. Throughout the campus and parks there are areas underneath the overstory canopy with an absence of trees, indicating the need for additional plantings. Advanced planning is necessary since it may take three to eight years to produce a $5 \mathrm{~cm}$ caliper tree.

Measuring the benefits of urban trees include both monetary and public or social values (Scott and Betters 2000; Miller 2007). An urban forest can enhance real estate values, reduce heating and cooling expenses, and improve aesthetics (McPherson 1992; McPherson et al. 1994). Although the SFASU campus trees were found in better health condition than those of the city parks, SFASU campus trees average economic value was less than that of city parks due to a smaller average size and different species composition.

Based on the CTLA tree valuation, the SFASU forest is an asset valued at more than \$27 million 
to the university, and would increase to $\$ 35$ million for all trees in optimum condition. However, there is $\$ 7$ million reduction in potential value (29\%) because of imperfect condition. A distinctive characteristic of urban forests is that when they mature, more maintenance is required. The results indicate that many campus trees currently receive less maintenance than needed. McPherson et al. (1999) indicate investment in the urban forest offers return to the citizens, and continued investment is needed. Planning and managing for the future will require careful planning and the development of a long-term urban forest management plan. A concerted effort is underway to remove hazard trees from the campus and to increase tree maintenance based on the results of this study.

The replacement value method is extremely useful when planning for tree removal, site cleanup, restoration, preparation, and additional maintenance expenditures. The demands to quantify the value of trees become even more important when trees are threatened by disease. Ellison (2005) indicated the need to balance the benefits of risk reduction with the associated costs of lost tree value and financial expenditure. Evaluating and mapping the tree population and identifying the interface between trees and targets prioritize risk assessments. The measurements of the tree condition in the current study can be used in risk assessment. Trees with lower condition values (Table 1; Table 2) indicate trees at greater risk. Risk includes dead or dying branches (Structure) while trunk defects include cracks and sporophores (Trunk). These trees require careful monitoring to ascertain further loss of condition. The value of these trees added to an ArcGIS 10.1 database provides the basis for future comparisons on an annual examination. As both of the study areas investigated are high traffic areas, both the proximity of the trees and target evaluation need to be considered. More frequent inspections of areas of high public access need to be considered with updates to the hazard rating data (Hickman et al. 1995; Ellison 2005). Hazard rating of campus and park trees needs to include the "prudent person" concept (Sharon 1987) for one that looks ahead and carefully provides for the future. Values, such as the cost to maintain declining trees and the removal of trees that have been killed by disease, can be derived based on the calculated dollar values. If the values people are paying for the trees need to be evaluated, another modeling method, predictive modeling, would be better to reflect those values (Martin et al. 1989).

More specialized software used for urban forest evaluation and management have been developed and widely used for professional GIS application with powerful database and GIS mapping techniques. Some advanced software, including Tree$\mathrm{Pro}^{\mathrm{Tx}}$ and CITYgreen, are designed to archive tree data and allow for tree evaluation in a more convenient way. Longcore (2004) conducted a case study in Los Angeles, California, U.S., in 2004, with CITYgreen software. Based on a geographic representation of the study area, Longcore analyzed the benefits of trees and greenspace and pointed out some limitations, including that the tree growth model seems to work well on young trees, but calculates unrealistically large future tree sizes for mature trees. Currently trees on the SFASU campus and in Nacogdoches city parks are being evaluated using i-Tree Design to determine benefits of the urban forest on rainfall interception, energy savings, benefits to air quality and carbon dioxide reduction. Abd-Elrahman et al. (2010) used i-Tree ECO to develop an urban forest inventory. This software, using the standards set by theISA, can track, value, and rate trees and generate reports containing assessed value, species, location, hazard rating, $\mathrm{DBH}$, height, and maintenance history. With that, trees would be evaluated and managed more easily and efficiently.

\section{SUMMARY}

The SFASU campus trees were significantly healthier than the city park trees. Among the most abundant twelve species, nine species had significant difference in tree health and showed significant difference in trunk condition. Trunk problems or wood decay were the most important factors concerning tree health condition. When using $\$ 75$ as the ISA value per square inch of cross-sectional area, the total value of all SFASU campus trees was over \$27 million compared to over $\$ 20$ million for the city park trees. However, SFASU campus trees had a lower average value than city park trees due to area sizes and different species composition. If all trees were in optimum condition, the total value of SFASU would increase to over $\$ 35$ million, implying a $30 \%$ loss in dollar value due to the undesirable condition. In the city parks, if all trees were in optimum condition, 
the value would increase by $28 \%$-to more than $\$ 25$ million in value. The SFASU campus and city parks trees are similar in biodiversity. Even though both SFASU forest and city parks appear to be fairly diverse with 79 and 44 individual tree species respectively, it is not biologically diverse. That is not desirable for tree management and disease control and may negatively affect urban tree health. New species should be introduced and understory trees need to be planted. GIS was useful to better understand the tree health situations and their spatial distributions as spatial analyses can be used to facilitate the focus on tree identification and maintenance.

Acknowledgments. This research was supported with a grant from the Texas A\&M Forest Service and McIntire Stennis funds administered by the Arthur Temple College of Forestry and Agriculture.

\section{LITERATURE CITED}

Abd-Elrahman, A.H., M.E. Thornhill, M.G. Andreu, and F. Escobedo. 2010. A community-based urban forestry inventory using online mapping services and consumer-grade digital images. International Journal of Applied Earth Observation Geoinformation 12:249-260.

Albers, J.S., J.D. Pokorny, and G.D. Johnson. 2003. Chapter 3: How to detect and assess hazardous defects in trees. pp. 41-116. In: J.D. Pokorny (Coord. Ed). Urban tree risk management: A community guide to program design and implementation. USDA Forest Service, Northeastern Area, NA-TP-03-03., St. Paul, MN.

Alvey, A.A. 2006. Promoting and preserving biodiversity in the urban forest. Urban Forestry \& Urban Greening 5:195-201.

Asociacion Española de Parques y Jardines Publicos. 1999. Metedo para valoración de arboles y árbustos ornamentales. Norma Granada. Asociacion Española de Parques y Jardines Publicos, Madrid, Spain.

Council of Tree \& Landscape Appraisers. 1992. Guide for Plant Appraisal (8th edition). International Society of Arboriculture, Champaign, Illinois, U.S. 103 pp.

Council of Tree \& Landscape Appraisers. 2000. Guide for Plant Appraisal (9th edition). International Society of Arboriculture, Champaign, Illinois, U.S. 143 pp.

Creech, D.L., J. Singhurst, D. Kulhavy, G. Seibel, and D. McDonald. 1994. The woodland vegetation of Stephen F. Austin State University revisited: A CAD/GIS analysis. HortScience abstract 28(5):482.

Cullen, S. 2007. Putting a value on trees-CTLA guidance and methods. Arboriculture Journal 30:21-43.

Dreesen, A.D. 1994. Evaluation of Texas shade trees. Texas Agricultural Extension Service, pub1-1683. 8 pp.

Dwyer, J.F., D.J. Nowak, M.H. Noble, and S.M. Sisinni. 2000. Connecting people with ecosystems in the 21st century: An assessment of our nation's urban forests. Gen. Tech. Rep. PNWGTR-490. Portland, OR: USDA, Pacific Northwest Research Station. 483 pp.

Ellison, M.J. 2005. Quantified tree risk assessment used in the management of amenity trees. Journal of Arboriculture 31:57-65.
Fischer, J., D.B. Lindenmayer, and A.D. Manning. 2006. Biodiversity, ecosystem function, and resilience: Ten guiding principles for commodity production landscapes. Frontiers in Ecology and the Environment 4(2):80-86.

Flook, R. 1996. A Standard Tree Evaluation Method (STEM). Ron Flook, Tahunanui, Nelson, New Zealand.

Gilbert, E.A., and E.T. Smiley. 2004. PiCUS Sonic Tomography for the quantification of decay in white oak (Quercus alba) and hickory (Carya spp.). Journal of Arboriculture 30(5):277-281.

Grande-Ortiz, M.A., E. Ayuga-Téllez, and M.L. Contato-Carol. 2008. A comparative analysis of methods for the valuation of urban trees in Santiago del Estero, Argentina. Spanish Journal of Agricultural Research 6(3):341-352.

Grande-Ortiz, M.A., E. Ayuga-Téllez, and M.L. Contato-Carol. 2012. Methods of tree appraisal: A review of their features and application possibilities. Arboriculture \& Urban Forestry 38(4):130-140.

Hauer, R.J., and G.R. Johnson. 2003. Chapter 1, Tree risk assessment. pp. 5-10. In: J.D. Pokorny (Coord. Ed.). Urban tree risk management: A community guide to program design and implementation. USDA Forest Service, Northeastern Area, NA-TP-03-03., St. Paul, MN.

Helliwell, D.R. 1967. The amenity value of trees and woodlands. Journal of Arboriculture (1):128-131.

Helliwell, D.R. 2000. Amenity valuation of trees and woodlands (revised edition). Arboricultural Association, Romsey, Hants, United Kingdom. 40 pp.

Hermy M., and J. Cornelis. 2000. Towards a monitoring method and a number of multifaceted and hierarchical biodiversity indicators for urban and suburban parks. Landscape and Urban Planning 49 (3-4):149-162.

Hickman, G.W., E. Perry, and R. Evans. 1995. Validation of a tree failure evaluation system. Journal of Arboriculture 21:223-234.

Hollis, A. 2012. A critical analysis of CTLA's depreciation factorsDo inherent inconsistencies of method complicate the simplicity of process? Arboriculture Journal: The International Journal of Urban Forestry 32(3):157-166.

International Valuation Standards Committee. 2005. International Valuations Standards, Seventh Edition. London. 459 pp.

Johnstone, D.M., P.K. Ades, G.M. Moore, and I.W. Smith. 2007. Predicting wood decay in eucalypts using an expert system and the IML-RESISTOGRAPH drill. Arboriculture \& Urban Forestry 33:76-82.

Johnstone, D., G. Moore, M. Tausz, and M. Nicolas. 2010. The measurement of wood decay in landscape trees. Arboriculture \& Urban Forestry 36:121-127.

Kane, B.C.P., and H.D.P. Ryan III. 2004. The accuracy of formulas used to assess strength loss due to decay in trees. Journal of Arboriculture 30:347-356.

Kane, B., D. Ryan, and D.V. Bloniarz. 2001. Comparing formulae that assess strength loss due to decay in trees. Journal of Arboriculture 27:78-87.

Longcore, T. 2004. Applicability of CITYgreen urban ecosystem analysis software to a densely built urban neighborhood. Urban Geography 25(2):173-186.

Luley, C. 2012. Indicators of decay in urban trees. Arborist News 21(3):18-20.

Martin, C.W., R.C.Maggio, and D.N. Appel. 1989. The contributory value of trees to residential property in the Austin, Texas metropolitan area. Journal of Arboriculture 15(3):72-76. 
McGarry, P.J., and G.M. Moore. 1988. The Burnley method of amenity tree evaluation. Australian Journal of Arboriculture 1:19-26.

McPherson, E.G. 1992. Accounting for benefits and costs of urban greenspace. Landscape and Urban Planning 22:41-51.

McPherson, E.G., D.J. Nowak, and R.A. Rowntree. 1994. Chicago's Urban Forest Ecosystem: Results of the Chicago Urban Forest Climate Project, General Technical Report NE-186. USDA Forest Service, Northeast. For. Exp. Sta., Radnor, PA. 201 pp.

McPherson, E.G., D. Nowak, G. Heisler, S. Grimmond, C. Souch, R. Grant, and R. Rowntree. 1997. Quantifying urban forest structure, function, and value: The Chicago Urban Forest Climate Project. Urban Ecosystems 1:49-61.

McPherson, E.G., J.R. Simpson, P.J. Peper, and Q. Xiao. 1999. Benefitcost analysis of Modesto's municipal urban forest. Journal of Arboriculture 25:235-248.

Miller, R. 2007. Urban Forest Planning and Managing Urban Green Spaces, 2nd edition. Prentice Hall, Upper Saddle River, New Jersey, U.S.

Nicholas, D., and D. Crawford. 2003. Concepts in the development of new accelerated test methods for wood decay. American Chemical Society 1:288-312.

Nixon, E.S., and C.W. Mims. 1971. The woodland vegetation of Stephen F. Austin State University: Biology Department Bulletin No.1.

Noss, R.F. 1999. Assessing and monitoring forest biodiversity: A suggested framework and indicators. Forest Ecology and Management 115(2-3):135-146.

Nowak, D.J., D.E. Crane, and J.F. Dwyer. 2002. Compensatory value of urban trees in the United States. Journal of Arboriculture 28(4):94-199.

Parker, H.D. 1988. The unique qualities of a geographic information system: A commentary. Photogrammetric Engineering and Remote Sensing 54:1547-1549.

Perkins, S.L. 1996. Shade tree analysis of the Stephen F. Austin State University core campus. Master of Science thesis, Stephen F. Austin State University, Nacogdoches, TX.

Petijean, M.L., D.P. Ryan, and D.V. Bloniarz. 1997. Establishing the value of street trees. Northeast Center for Urban and Community Forestry Newsletter 1(2):1-8.

Pokorny, J.D. (Coord. Ed.). 2003. Urban tree risk management: A community guide to program design and implementation. USDA Forest Service, Northeastern Area, NA-TP-03-03., St. Paul, MN

Pokorny, J.D., and J.S. Albers. 2003. Chapter 2: Community tree risk management: Program planting and design. pp. 11-40. In: J.D. Pokorny (Coord. Ed.). Urban tree risk management: A community guide to program design and implementation. USDA Forest Service, Northeastern Area, NA-TP-03-03., St. Paul, MN.

Raupp, M.J., A.B. Cumming, and E.C. Raupp. 2006. Street tree diversity in eastern North America and its potential for tree loss to exotic borers. Arboriculture and Urban Forestry 32:297-304.
Rogers, W.E., and E. Siemann. 2005. Herbivory tolerance and compensatory differences in native and invasive ecotypes of Chinese tallow tree (Sapium sebiferum). Plant Ecology 181:57-68.

Santamour, F.S., Jr. 2004. In: C.R. Elevitch (Ed.). The Overstory Book: Cultivating Connections with Trees, 2nd Edition. pp. 396-400. Permanent Agricultural Resources, Holualoa, HI.

Schaefer, V. 2009. Alien invasions, ecological restoration in cities and the loss of ecological memory. Restoration Ecology 17:171-176.

Scott, J.L., and D.R.Betters. 2000. Economic analysis of urban tree replacement decisions. Journal of Arboriculture 26(2):69-76.

Sharon, M.E. 1987. Tree health management: Evaluating trees for hazard. Journal of Arboriculture 13:285-293.

Smiley, E.T., and F.A. Baker. 1988. Options in street tree inventories. Journal of Arboriculture 14(2):36-42.

Spellerberg, I.F., and P.J. Fedor. 2003. A tribute to Claude Shannon (1916-2001) and a plea for more rigorous use of species richness, species diversity and the 'Shannon-Wiener' Index. Global Ecology and Biogeography 12(3):177-179.

Vannatta, A.R., R.H. Hauer, and N.M. Schuettpelz. 2012. Economic analysis of emerald ash borer (Coleoptera: Buprestidae) management options. Journal of Economic Entomology 105(1):196-206.

Watson, G. 2002. Comparing formula methods of tree appraisal. Journal of Arboriculture 28(1):11-18.

Webster, C.R., M.A. Jenkins, and S. Jose. 2006. Woody invaders and the challenges they pose to forest ecosystems in the eastern United States. Journal of Forestry 104:366-374.

David L. Kulhavy (corresponding author)

Arthur Temple College of Forestry and Agriculture

Stephen F. Austin State University

Nacogdoches, Texas 75962, U.S.

dkulhavy@sfasu.edu

$D i W u$

Arthur Temple College of Forestry and Agriculture

Stephen F. Austin State University

Nacogdoches, Texas 75962, U.S.

Daniel R. Unger

Arthur Temple College of Forestry and Agriculture

Stephen F. Austin State University

Nacogdoches, Texas 75962, U.S.

I-Kuai Hung

Arthur Temple College of Forestry and Agriculture

Stephen F. Austin State University

Nacogdoches, Texas 75962, U.S.

J. H. Sun, Institute of Zoology

Chinese Academy of Science

Beijing, 100101, P. R. China 
Zusammenfassung. Bäume in Landschaften werden mittels ihrer physischen und ihrer ästhetischen Eigenschaften und Biodiversität bewertet. Die Bäume auf dem Uni-Kampus und in den Stadtparkanlagen helfen dabei, eine geeignete Umwelt zum Studieren und Entspannen von Studenten und Besuchern zu liefern. Es stellt eine kritische Herausforderung für die urbanen Forstverwalter, Arboristen und Planer dar, eine Entscheidung zu treffen, wenn ein Baum entfernt und ersetzt werden soll: diese Entscheidung ist oft basierend auf der Baumgesundheit, dem Zustand und den Sicherheitserwartungen. Dieses Projekt untersuchte auf dem Kampus der Stephen F. Austin State University (Nacogdoches, Texas, U.S.) insgesamt 3.345 Bäume von 79 Arten und 1.572 Bäume aus 44 Arten in den Stadtparkanlagen von Nacogdoches. Die Baumgesundheit und der Ersatzwert wurden für beide Gruppen statistisch verglichen, ebenso wie die Artenzusammensetzung (Diversität). Zum Schluss wurden die Kondition und die Verteilung der Bäume geographisch mit einem GIS-Programm zugeordnet und analysiert. Es gab statistische Beweise dafür, dass die Bäume auf dem Kampus deutlich gesünder waren als die im Park, aber keine ihrer Diversität war zufrieden stellend. Es ist wichtig, Bäume mit starken Fäulen zu identifizieren und zu entfernen sowie neue Arten einzuführen, wenn forstliche Pflegemaßnahmen und Management durchgeführt werden.
Resumen. Los árboles en los paisajes urbanos son valorados por sus beneficios físicos así como estéticos y la biodiversidad. Los árboles en un campus universitario y en parques de la ciudad también ayudan a proporcionar un ambiente para los estudiantes y visitantes para estudiar y relajarse. Una decisión crítica que enfrentan los dasónomos urbanos, arboristas y planificadores implica decidir cuándo un árbol debe ser removido y reemplazado, por lo que es una decisión a menudo basada en una evaluación de la salud del árbol, condición y preocupaciones de seguridad. Este proyecto contempló un total de 3345 árboles con 79 especies en el campus de Stephen F. Austin Universidad Estatal (Nacogdoches, Texas, EE.UU.) y 1572 árboles con 44 especies en parques de la ciudad de Nacogdoches. Se compararon estadísticamente los valores de la salud y sustitución de árboles de los dos grupos, al igual que su diversidad. Por último, las condiciones de salud y la distribución de los árboles fueron analizadas espacialmente usando un sistema de información geográfica. Aunque no hubo evidencia estadística que indique que los árboles del campus fueron significativamente más saludables que los árboles del parque de la ciudad, ni de su estado de biodiversidad era deseable. Es importante identificar y eliminar los árboles con gran deterioro de la madera e introducir nuevas especies al realizar el mantenimiento y gestión de los bosques urbanos. 